Columbia Law School

Scholarship Archive

1993

\title{
Copyright Without Walls?: Speculations on Literary Property in the Library of the Future
}

Jane C. Ginsburg

Columbia Law School, jane.ginsburg@law.columbia.edu

Follow this and additional works at: https://scholarship.law.columbia.edu/faculty_scholarship

Part of the Intellectual Property Law Commons

\section{Recommended Citation}

Jane C. Ginsburg, Copyright Without Walls?: Speculations on Literary Property in the Library of the Future, 42 REPRESENTATIONS 53 (1993).

Available at: https://scholarship.law.columbia.edu/faculty_scholarship/2260

This Article is brought to you for free and open access by the Faculty Publications at Scholarship Archive. It has been accepted for inclusion in Faculty Scholarship by an authorized administrator of Scholarship Archive. For more information, please contact scholarshiparchive@law.columbia.edu. 
Copyright without Walls?: Speculations on Literary Property in the Library of the Future Author(s): Jane C. Ginsburg

Source: Representations, No. 42, Special Issue: Future Libraries (Spring, 1993), pp. 53-73

Published by: University of California Press

Stable URL: https://www.jstor.org/stable/2928618

Accessed: 28-09-2018 19:08 UTC

\section{REFERENCES}

Linked references are available on JSTOR for this article:

https://www.jstor.org/stable/2928618?seq=1\&cid=pdf-reference\#references_tab_contents You may need to log in to JSTOR to access the linked references.

JSTOR is a not-for-profit service that helps scholars, researchers, and students discover, use, and build upon a wide range of content in a trusted digital archive. We use information technology and tools to increase productivity and facilitate new forms of scholarship. For more information about JSTOR, please contact support@jstor.org.

Your use of the JSTOR archive indicates your acceptance of the Terms \& Conditions of Use, available at https://about.jstor.org/terms

University of California Press is collaborating with JSTOR to digitize, preserve and extend access to Representations 


\section{Copyright Without Walls?: Speculations on Literary Property in the Library of the Future}

\section{Introduction}

This eSSAY CONSIDERS THE application and adaptation of copyright law to the library of the future. ${ }^{1}$ In this "library without walls," works will be accessible by computer to users near and far. While a printed book usually is read by only one person at a time, that same book in digital format may be simultaneously consulted by as many users as have PCs linked by modem to the library. Where collecting quotations from printed sources today requires transcription or photocopying, in the library of the future it may be possible to download and print out excerpts, or even the entire work, through the user's personal computer.

All of these uses involve reproductions or transmissions of the accessed works. Unless the works are in the public domain, these uses, if unauthorized, may be copyright infringements - at least under today's doctrines. Are literary property rights as we have known them inimical to a networked environment? Or can there be copyright without walls? If copyright requires "walls," what will replace it, and will the replacement prove more satisfactory to libraries and their users? Although some librarians have lamented the restrictive effects of copyright, and perceived overreaching applications by publishers, ${ }^{2}$ a world without copyright may prove even less user-friendly. The reason is simple: in such a world, the information supplier, relying on contract, forgoes the benefits of the copyright law, but also evades important limitations on the copyright monopoly, notably the fair use privilege. In such a world, librarian-users might look back on existing copyright law with wistful nostalgia.

To project the future of copyright in the library of tomorrow, it will be helpful first to set the stage by briefly reviewing the role of copyright in the operations of the library of today. In the library of tomorrow the past will long remain present: copyright issues are posed when the library scans printed documents and distributes them in digital format. I will therefore consider copyright issues that arise in the transition from hard copy to digital media.

The second part of this essay will posit an information world of tomorrow in which all documents are available from the outset in digital format-indeed, 
some of them may be available only in that format. In this context, a variety of copyright questions presents itself to tomorrow's librarians. Some of these issues concern the library as a conduit for information originating elsewhere: How will the library obtain access to these documents, particularly if it is not a national deposit library? On what basis can the library make this access available to users? More broadly, does copyright have any remaining role in a digital environment in which information suppliers impose contractual conditions on access to works?

Other issues derive from the library's role as a generator of information, such as catalogs and summaries of documents both within and outside the library's own holdings. In this context, predictions of copyright's infirmity may well prove premature. The library may both create its own copyrighted works and infringe others'. The library may be a copyright proprietor of the bibliographic database if it extends even a modicum of creativity to its selection or organization of the information. But if its database substantially reproduces works contained in the catalog, the library may also be infringing literary property rights in the referenced works.

\section{Copyright and the Hard-copy Library}

Copyright and the library of the recent past. Until the advent of the photocopier, a library's activities rarely, if ever, implicated copyright considerations. A library circulated books and other documents; it did not copy them. Copyright comprises the exclusive-incorporeal-rights to reproduce and publicly perform or transmit works; ${ }^{3}$ it does not reach the physical object that embodies the work. Thus, once the copyright owner sold a copy of the work, that copy-in its physical manifestation-became the personal property of its new owner, who could resell, lend, or otherwise dispose of her chattel. ${ }^{4}$ So long as the library simply rotated possession of the book, the library remained fully within its rights as a property owner. ${ }^{5}$ Library patrons might, of course, manually copy or type out portions of the book for personal use, but these limited reproductions would have fallen within the "fair use" and "fair dealing" exemptions of U.S. and Commonwealth law, or under explicit private copying privileges found in continental copyright legislation. ${ }^{6}$

Once libraries began to avail themselves of the photocopier, however, they could no longer neglect copyright considerations. Photocopying could be used to preserve books and to fill gaps in collections when original formats were no longer available. Beyond these functions, photocopying could increase the library's ability to service users by multiplying the number of available copies or parts of copies. But once copies are being made, copyright issues are posed. ${ }^{7}$

To evaluate the severity of the copyright challenge, it is necessary to sketch 
the contours of the U.S. "fair use" privilege, and its foreign-law analogs. Most, if not all, copyright laws afford certain exemptions from the author's or copyright owner's rights. One of the most widespread exceptions excuses copying that does not substitute for sale or licensing of the work. ${ }^{8}$ In the U.S. "fair use" exception, the question of potential economic harm caused by copying is central, but the broader public-interest issue of access to knowledge weighs heavily in the balance as well, especially when the reproduction is made for nonprofit educational purposes. ${ }^{9}$ In addition, in the 1976 Copyright Act Congress set forth special highly detailed rules under which libraries could engage in unauthorized copying. ${ }^{10}$ These rules generally exempt archival copying ${ }^{11}$ but would not permit a library to substitute photocopies for regular acquisitions. ${ }^{12}$

The U.S. Copyright Act also details circumstances in which libraries may make copies of works or portions of works for users for their private study or scholarship. ${ }^{13}$ Because the statute circumscribes the instances in which libraries may supply copies of documents to patrons, an important copyright issue concerns the provision of photocopies to persons outside the scholarly and nonprofit communities. Many libraries, particularly legal, medical, and scientific libraries, have clients who pay for the library's services. If these clients are not nonprofit institutions, any "fair use" claim is likely to be questionable. These clients may be able to save time and money by using a library to deliver documents; however, there is no reason they should be able to save additional money at the expense of the copyright holder. ${ }^{14}$ In these instances, libraries charge and remit royalties to the Copyright Clearance Center (CCC), a consortium of publishers that collectively licenses its repertory of works to various users, including university libraries. The collective licensing mechanism permits the library to copy any and all of the licensed works, without having to obtain separate permissions each time a copy is made. ${ }^{15}$ If the copyright owner of the client-requested work is not a member of the CCC and has no other licensing program with the library, the library is supposed to seek permission to copy each work each time an outside request is made. Not surprisingly, this can be a burdensome process.

Organizations for the collective licensing of photocopy rights exist in many other countries as well. In some countries, collective licensing resembles the activities of the CCC: libraries may remit the monies, but the fees are actually paid by the libraries' users. In others, however, the government may negotiate with the collectives to pay a sum covering all photocopying in educational institutions, thus covering nonprofit end users, such as students and teachers, as well. ${ }^{16}$

Scanning the role of copyright in the transition to digital libraries. Many libraries are converting portions of their print collections to digital format. At the time they acquired the works they now intend to scan, the libraries may not have negotiated digital conversion rights. If the works thus to be converted are still protected by copyright, in what instances must permission to digitize be secured? 
Putting the work into digital format is only the beginning, from both a copyright holder's and a user's point of view. Once the work has been converted, it can be accessed in several ways. It can be viewed on-screen, it can be printed out, and it can be downloaded. Under copyright law, all of these constitute reproductions. ${ }^{17}$ Which, if any, modes of access might be considered "fair use" or benefit from another copyright exception? Analysis will require analogizing digital access to the kinds of reproductions that qualified for exemptions in the hard-copy world. Applying the rules of yesterday's library to regulate use of technologies that will radically transform tomorrow's library might seem like trying to use a phonograph designed for wax cylinders to play a CD. Nonetheless, this analysis may at least help identify those areas in which current copyright rules may require reshaping.

Conversion to digital format. Converting a hard-copy work to computerreadable form entails reproducing the work. If the work is scanned, it is first reproduced as an "image file," containing an electronic picture of the pages. If that file is then converted to ASCII form,${ }^{18}$ the resulting "text file" constitutes the creation of another reproduction. Because the copyright owner normally enjoys the exclusive right to reproduce the work, must the library therefore secure permission to perform the conversions? I would anticipate that, at least in the U.S., rules that today afford libraries exemptions for archival photocopying also apply to optical scanning and text-file creation for the same purposes. If the library is permitted to make the copy, it should not matter what technology was employed to generate the reproduction. ${ }^{19}$

Making the file available to reader-viewers raises a different problem. For a printed text, reading presents no copyright issues because copyright does not attach to the physical object. In the digital world, however, looking at the text does implicate copyright, because viewing the text on-screen entails making a reproduction of the text. ${ }^{20}$ The question therefore arises whether the digital equivalent of "looking at a book" requires the copyright owner's permission. I suspect that, although this act of viewing is analytically prima facie copyright infringement, were the issue to be litigated a court would excuse the copying as fair use. Although the work's format is different, the library is providing the same service of making the work available to users. A policy favoring easy and inexpensive public access to works of authorship underlies the fair use exemption. ${ }^{21}$ A court may therefore be unlikely to look sympathetically on a copyright holder's attempt to impose a pay-per-view requirement simply to access the work when no permanent copies are made.

The preceding discussion has addressed the access question as if the library would treat the digital copy like a hard copy, making it available only to one user at a time. In fact, however, digital copies, unlike hard copies, can be made available simultaneously to as many users as a network or online service permit. Establishment of a digital copy therefore can lead to a multiplication of user copies. 
Creation of text files in order to multiply the number of copies in the library's collection would also, at least under today's rules, fall outside the free-copying boundary. ${ }^{22}$ The practical effect of converting a text from hard copy to digital is the creation of digital copies in addition to-or in lieu of-hard copies; accordingly, unless it determined to forgo one of the signal benefits of digital technology-multiplicity of access - the library will have to confront the copyright consequences of multiple reproductions. Thus, copyright considerations necessarily influence a library's disposal of its digital files, even if no copyright was infringed when the file was initially established.

For example, suppose the library wished to preserve its copy of a work still protected by copyright, such as Herbert Howell's 1942 treatise on copyright law, ${ }^{23}$ which we will assume was printed on acid paper and is slowly but surely burning itself up. We will further assume that the book is out of print, and unavailable at a reasonable price from other sources. In the U.S., these facts would entitle the library to convert the book to digital format. They would also permit the library to make the digital copy available to one user at a time. But they would not entitle the library to make the digital copy available to many users at a time. That kind of reproduction would require the authorization of the copyright holder.

By the same token, suppose that the library had multiple copies of certain high-demand, in-print books, such as Allan Farnsworth's treatise on contract law, and that the library wished to save shelf space by substituting digital copies for all but one hard copy. The first question is whether the library may establish the initial digital file without the copyright owner's permission. Because this work is currently available, the library cannot avail itself of an archival copying exception; it would, therefore, probably need permission to digitize in the first place.

How many copies may the library simultaneously generate from the Farnsworth digital file? Arguably, the library should be able, without permission, to create as many digital copies as it had hard copies. But this argument is weak; after all, if a library had four copies of a commercially available text, and loses three because borrowers fail to return them, the library is not entitled to free photocopies to restock its inventory. ${ }^{24}$ Moreover, the library's privileges "extend to the isolated and unrelated reproduction . . . of a single copy"; they do not cover "concerted reproduction" of "multiple copies of the same material, whether made on one occasion or over a period of time." ${ }^{25}$ Systematic substitution of digital for hard copies of particular works seems more like "concerted" than "isolated and unrelated" reproductions. As a practical matter, however, this question may not arise in this fashion: once the library must negotiate with the copyright owner to engage in the initial digitalization, it should also negotiate the number of copies, and the further reproductions that users make from them.

Copying from the digital copy. Let us assume that we are starting from a text file that the library created either within the bounds of the library's free-copying or fair use privileges, or with permission from the copyright owner. We already 
know that making that file available to more than one user at a time means reproducing the work in a manner exceeding the traditional library prerogatives. The copyright owner will therefore assert legal control over the amount of and manner of access to the work. Similarly, the copyright owner will wish to regulate any further reproductions that libraries or users might make by printouts or downloading. Indeed, the owner might demand compensation for certain reproductions that would otherwise qualify for an exemption under the library copying or fair use provisions. Because the U.S. Copyright Act explicitly permits contractual override of the library copying privileges,${ }^{26}$ it is foreseeable that, once the library is required to negotiate with the copyright owner in order to obtain permission to digitize at all, or to make more than one simultaneous copy, the copyright owner will endeavor to impose a host of additional conditions on access to and further reproduction of the work. ${ }^{27}$

On the other hand, if the library enjoyed a privilege initially to digitize the work and it restricts availability to one user at a time, the copyright owner would have no claim to demand additional compensation unless any further reproductions made by the library or its users exceeded the statutory exemptions. It is important to consider the application of these exemptions in the digital environment. This examination requires not only transposing the copying media from photocopying to printouts and downloading, but also evaluating whether the transposition leads to results inconsistent with the policies underlying the current rules.

Reproductions that currently qualify for exemption under U.S. law include a user's printing out or downloading short excerpts for private study or scholarship ${ }^{28}$ and a library's provision of a copy of even an entire work to a user for private study or scholarship when an original is no longer available at a fair price. ${ }^{29}$ However, in the second case, one might anticipate that the library should make such a reproduction available only in hard copy. A digital copy too easily lends itself to further reproduction, thereby undermining the reprint or reissue markets for the work and exceeding international norms of exempted reproductions. ${ }^{30}$

For the same reason, in those countries that permit free "private copying" of entire works, the exemption should be tailored to exclude private copying by means of downloading. Even if the further digital copy is made for purely private purposes, the medium so enhances the copy's potential to be fruitful and multiply that temptation is best avoided. Similarly, the provision of the U.S. copyright law that exempts a library from liability for copies made by patrons if the copies were produced on equipment made available, but unsupervised by, the library, requires rethinking. ${ }^{31}$ While the exemption might continue to apply for useraccessible printers attached to workstations, the library should be liable if, without the copyright owner's permission, it makes equipment available to users that enables them to download entire files. ${ }^{32}$ 
Interlibrary loan practices afford a further illustration of the potential incompatibility of the current library copying exemptions and the electronic environment. The U.S. Copyright Act permits libraries to "participat[e] in interlibrary arrangements that do not have, as their purpose or effect, that the library or archives receiving such copies or phonorecords for distribution does so in such aggregate quantities as to substitute for a subscription to or purchase of such work." 33 Sending digital copies on interlibrary loan could achieve precisely that effect-because once a library acquired a digital copy, absent further limitations, the library would no longer require hard copies (or publisher-authorized digital copies). Were digital-format works to be made available through interlibrary loan, the originating library should at least accompany any freestanding digital version, such as a floppy disk, with limitations as to the number of users and the kinds of further reproductions. Similar limitations should apply to copies sent via electronic mail. Alternatively, the originating library could restrict the requesting library to online access from the originating library while denying permission to download; authorized downloading would be subject to the requesting library's agreement to destroy the copy.

Several of the accommodations just proposed have in common the attempt to respond to the transition to "libraries without walls" by erecting walls wherever possible. Thus, in a model in which hard-copy copyright concepts continue to dominate, fair use will remain shaped by the model of the printed book. That means, for example, that the law imposes a wall between the first, free, digital onscreen copy and the subsequent multiple copies that can be viewed simultaneously. The law maintains walls between documents and users by obliging libraries to limit user access to onscreen views or short printouts, because access by downloading too easily lends itself to generation of uncontrollable user copies.

These accommodations, and the concepts underlying them, will require further evaluation and adjustment in the library of tomorrow in which the documents originate from publishers in digital form. ${ }^{34}$

\section{Copyright and Contract in the Digital Library}

Copyright law has supplied protection to authors who could not otherwise control the exploitation of their works. It has traditionally presumed a world in which, but for copyright, unauthorized reproductions would be pervasive and unremediable. As Justice Holmes observed, "In copyright, property has reached a more abstract expression. The right to exclude is not directed to an object in possession or owned, but is now in vacuo, so to speak. It restrains the spontaneity of men where, but for it, there would be nothing of any kind to hinder their doing as they saw fit. It is a prohibition of conduct remote from 
persons or tangibles of the party having the right. It may be infringed a thousand miles from the owner and without his ever becoming aware of the wrong." 35

In the library of the future, these assumptions may no longer apply. Today, I will not know if a library user in Berkeley, in Boston, in Bonn, or in Brisbane is photocopying this article. ${ }^{36}$ But tomorrow, when "we are all connected," and this article is available worldwide online, I will have the means to know who is reading the article onscreen, and who is downloading or printing out excerpts or complete copies. Here, as elsewhere, knowledge is power: I (or my digital publisher) can condition online access to my article on compliance with whatever restrictions I wish to impose.

Libraries as conduits for digital information: acquisitions and restrictions on use. In imagining a world in which most new works will be available in digital format, and in which many will be available only in digital format, I have suggested that one question is whether copyright retains any relevance. Another question is whether libraries retain any relevance. After all, if users may obtain the information by logging onto the publisher, or onto a third-party information provider such as Dialog or Prodigy, what use does a library serve? The user need no longer go to a place where works are gathered; assembly of works from many sources will be accomplished by modem. The library itself will be an electronic phenomenon, affording digital access to its own and to others' collections of works. Why should an information provider resort to the conduit of a library, when it can connect directly to the user? If the provider nonetheless gives libraries access to its information, how will the provider control the information so that the library does not displace the provider's customers? ${ }^{37}$

From the publisher's perspective, libraries may still afford valuable publicity for their works, and may reduce the transactions costs of dealing with individual users. Libraries may also become the repositories of digital files whose commercial value has ebbed; although library acquisitions of current material may pose conflicts with a publisher's program of dissemination, libraries may become storehouses of older works whose retention would be burdensome for the publisher, but which still have importance for scholars. From the user's perspective, tomorrow's library may resemble a full-service "help line"; the librarian of tomorrow will assist users in understanding and navigating the myriad available databases and other digital sources.

If digital publishers determine that it remains worthwhile to give libraries access to their works, they will almost certainly seek to condition that access upon compliance with a variety of restrictions. Publishers may wish to prevent certain kinds or quantities of user reproductions, or to charge for all uses over single viewings of the document. Publishers could enforce these limitations directly if the library is simply providing the user with a computer connection to the publisher. Publishers then could themselves limit initial access (onscreen viewing) to 
certain categories of users; they could prescribe a maximum number of bytes to be reproduced by printing out or downloading; or they could completely prohibit downloading.

Digital documents that are distributed in freestanding format, such as CDROMs, may prove more susceptible to unlicensed copying than online sources. Once the document leaves the producer's control, the producer cannot know firsthand who is viewing, who is copying, and how many copies are being made. Nonetheless, technology affords the producer a variety of extra-copyright protections. For example, the library would not be permitted to make the CD-ROM directly accessible to users, but would be obliged to make it available through the library's local-area network (LAN). Such a network would respond to individual user-access codes, enabling the library either to screen out or to charge more for certain kinds of users identified by the publisher. The LAN could be programmed to limit or prohibit printing or downloading. Moreover, both CDROMs and online services could be "booby-trapped" to prevent unauthorized printing out or downloading, for example, by flashing warnings that the user's request may not be fulfilled; by "freezing" if the user attempts to make a further copy; or even by sending a virus to the user's disk if the user persists.

Contracting out of fair use. Some of the limitations sought by digital publishers might override rights of libraries and users under fair use and library copying privileges, even after these privileges have been adjusted to account for the greater potential of digital copies to supersede or compromise the publisher's market. The U.S. Copyright Act provides that the library's privileges in no way affect "any contractual obligations assumed at any time by the library or archives when it obtained a copy or phonorecord of a work in its collections." 38 It seems clear, therefore, that the policies underlying these exceptions to copyright protection are not violated if the library agrees to forgo its privileges.

The same provision of the U.S. Copyright Act also states that the library's special statutory privileges in no way affect "the right of fair use," 39 and the legislative report accompanying the 1976 Act indicates that the special privileges accorded to libraries give them greater leeway to copy than they would enjoy by application of fair use alone. ${ }^{40}$ Fair use in effect affords libraries and users some kind of free-copying "safety net." One should inquire, therefore, whether a library's agreement with a publisher to forgo whatever free-copying privilege might be available under fair use is permissible under the copyright law.

In addressing this question, one might first inquire why copyright law is at issue at all. In the world here posited, the publishers abandon copyright and seek to regulate all use by contract, on the premise that where copyright's protections have nothing more to offer them than do contract and technological controls, copyright taken together with its exceptions, particularly fair use, offers them less. In pressing a contract claim, the publisher is seeking to achieve copyright- 
like protection, unencumbered by copyright's countervailing limitations. Do the Copyright Act and the federal policies underlying it permit enforcement under state contract law of what one might call the publisher's re-edition of copyright?

This question calls for application and analysis of federal preemption doctrine. The Copyright Act precludes state law claims when the subject matter to be protected is copyrightable, and when the rights asserted are equivalent to exclusive rights under copyright. ${ }^{41}$ Since what the publisher purveys almost always constitutes "original works of authorship," ${ }^{42}$ the first prong of the preemption test will usually be met. The right asserted by the publisher is the right to prevent copying; this appears equivalent to the exclusive right under copyright to reproduce the work in copies. ${ }^{43}$ However, substantial authority supports the proposition that rights under contract are not equivalent to rights under copyright. The nonequivalence derives from the difference between a contract and a property-right claim. A contract binds only those who are parties to it. A property right, such as a copyright, is good "against the world"; it is not based on any relationship between the party having the right and the party allegedly infringing the right. Hence Justice Holmes's statement that copyright "is a prohibition of conduct remote from persons or tangibles of the party having the right." A property right confers something in the nature of a monopoly in its object; a contract right governs relationships between persons, it does not regulate things.

Thus, in cases in which plaintiffs have invoked contracts granting them protection unavailable under copyright, courts have rejected preemption challenges. As one court stated: "A party by contract may agree to pay for ideas, even though such ideas could not be protected by copyright law. Rights under such an agreement are qualitatively different from copyright claims, and their recognition creates no monopoly in the ideas involved." 44

Judicial enforcement of contracts barring one party from copying the other's ideas is particularly noteworthy, because the federal determination not to protect ideas under copyright is very clear. The Copyright Act explicitly provides "in no case does copyright protection for an original work of authorship extend to any idea." 45 One might argue that this implies that no legal protection should be available, whatever the source. ${ }^{46}$ By upholding contracts that confer greater rights than copyright affords, these cases necessarily reject that proposition. As a general matter, moreover, U.S. intellectual property preemption decisions do not sustain the objection that limitations inherent to a formal intellectual property regime cannot be avoided by resort to a state law doctrine that dispenses with those constraints, at least when other constraints accompany the state law protection. The Supreme Court has, accordingly, declined to find state trade secret laws preempted by federal patent laws, even when they bear on the same subject matter. ${ }^{47}$ While patent protection is of short duration (seventeen years), and requires the patent holder to disclose the invention, a trade secret lasts as long as it remains a secret and, by definition, carries no requirement of disclosure. 
Though patent laws demonstrate a strong public policy in favor of making the invention available and understandable so that others may build on it, trade secrets advance none of those goals.

Nonetheless, the Supreme Court held that neither did trade secrets conflict with those goals, because trade secret protection was far more fragile than patent protection. Unlike patents, trade secrets do not protect against independent generation of the invention or against reverse engineering. In essence, trade secrets govern relations between the trade secret proprietor and those persons, such as employees, that she permits, in confidence, to learn the secret. Most trade secret cases concern a breach of that confidential relationship. ${ }^{48}$ Trade secrets thus offer an illustration of the successful resistance of a state law information right to federal intellectual property preemption. What saves the state law right appears to be its contractual (and therefore relatively weak) nature, even though one must acknowledge that the party advancing the contract would endeavor to push that contract right as close to a property right as possible.

But what if the premise underlying the nonpreemption cases proved false? In the digital environment posited here, contract protection may not be the fragile creature presumed in prior intellectual property preemption decisions. If access to works could be obtained only through the information provider (directly or through an authorized online distributor), and if copying could be electronically tracked or prevented, no "third parties" to the contract would exist. When "we're all connected," no functional difference may exist between a contract and a property right. At that point, it becomes necessary to consider whether limitations incorporated in the copyright law should be imported to its contractual substitute. With respect to libraries and their users, one should inquire whether some kind of fair use exception is appropriate. This might take the form of a judgemade right of "fair breach," or legislatively imposed mandatory library-user rights. ${ }^{49}$

Such exceptions could be appropriate if they salvaged important copyright policies that would otherwise be frustrated in the move from copyright to contract. But the policies underlying fair use can be variously described, and not all characterizations conflict with the contract regime here imagined. Under one approach, fair use is a response to market failure: when the copyright owner cannot efficiently license the kind of copying in which the defendant is engaged, the use may proceed unlicensed. ${ }^{50}$ If, by contrast, there exist "reasonably priced, administratively tolerable licensing procedures," ${ }^{51}$ no gap exists for fair use to fill, and there is no need for the exemption. The contractual regime discussed here is consistent with this characterization, because the publisher can charge for every kind of use, and the electronic media can keep track of it all.

Nevertheless, fair use can also be described as an exception to the copyright owner's prerogatives, or even as a subsidy from the copyright owner, in favor of uses that benefit the public. This interpretation emphasizes the constitutional 
purpose of copyright to "promote the progress of science (knowledge)." If, in certain instances, the law upheld the copyright owner's refusal to license the kind of copying in which a defendant seeks to engage, we would be permitting copyright to hinder rather than promote the progress of knowledge. ${ }^{52}$ The progress of knowledge would be impeded because a defendant would have incorporated copied material into a new endeavor, such as a work of criticism or scholarship, that would have contributed to public enlightenment. ${ }^{53}$

That the "public benefit" rationale for fair use would mandate grafting a fair use exception onto our imagined contract regime is not clear. This rationale has traditionally focused on "productive use" of the copied material in the creation of new works, for which copying from old works may be necessary; it does not necessarily supply a justification for "intrinsic" copying-copying of a work to make "ordinary" use of it. ${ }^{54}$ Yet under the 1976 Act, libraries have enjoyed some degree of fair use copying, even though that copying would seem to be for "intrinsic" purposes. Library copying remains consistent with the public benefit rationale, if one contends that access to the works is either the predicate for a subsequent productive use of them, or, more abstractly, promotes the progress of knowledge, because researchers will be enriched by what they read. ${ }^{55}$

A role for "fair use breach" or mandatory user rights could be imagined if publishers imposed conditions on libraries that denied meaningful access to their works. More likely, however, publishers will not deny such access; they will want to charge for it in ways they did not charge, and could not have charged, in the hard-copy world. Today, the effect of declaring a use "fair" is to make it free of charge. Perhaps in a digital world, fair use would not be an all-or-nothing matter; a court might uphold the copying at issue, but require the copyist to pay for it. The price the user would pay would be less than the price the informationprovider would have charged. In effect, a compulsory license regime might split the difference between user claims to free access and publisher initiatives to charge for all uses. ${ }^{56}$

But a compulsory license would be justified only if the publisher's rates were "unreasonable" according to criteria yet to be articulated. In the digital world, it remains to be examined if publishers will in fact make libraries pay "too much" for any access to documents. In a digital world, libraries could avoid the sunk costs of building and maintaining a paper collection. Online subscription would have to cost more on a yearly basis than hard-copy libraries cost, before the pricegouging objection would be borne out. Digital publishers might make libraries pay for simultaneous access beyond the first user, but this may still cost less than investing in additional hard copies. Moreover, competition among digital publishers should keep prices down. A more reasonable fear may be rooted in monopoly concerns: no competition exists because some publishers are the sole source of certain documents; these publishers, if unhappy in their negotiations with libraries, will someday pull the plug on the online system. In the hard-copy 
world, the library always is in possession of the books; in the digital world, if the online publishers cut the supply, the library is left with inert workstations.

This examination has shown that digital media, by enabling publishers to keep track of all the uses being made of their works, also give publishers the opportunity to charge for all uses, including those that would have been free in a hard-copy world. One may therefore fear that publishers will be sorely tempted to "overcharge" for access to and copying of their works, especially if there is no longer a fair use doctrine to hold them in check. However, we do not now know whether, even accounting for new publisher charges, digital media will also enable libraries to save money overall. Let us assume that library savings do not offset publisher increases when contract replaces copyright regulation of library acquisition and use of digital works. A need may nonetheless exist to impose a fair use exception or other means of price control. If so, the law regulating booksellers will have come full circle from the 1710 English Statute of Anne, the precursor to our copyright law. While that statute was the first copyright act, it was not limited to granting authors exclusive literary property rights. Knowing that copyright-vested authors would assign their rights to printers and booksellers (antecedents of modern publishers), and suspicious of the booksellers, the English Parliament included a mechanism for review and reduction of book prices. Should books be sold "at such a Price or Rate as shall be Conceived by any Person or Persons to be High and Unreasonable," that person could complain to a variety of authorities who were empowered to summon the publisher "to Examine and Enquire of the reason of the Dearness and Inhauncement of the Price or Value of such Book or Books." If the price were deemed unreasonable, the inquiring official enjoyed "full Power and Authority to Reform and Redress the same, and to Limit and Settle the Price of every such Printed Book and Books, from time to time, according to the best of their Judgments, and as to them shall seem Just and Reasonable." ${ }^{57}$ However, the history of this provision of the Act of Anne does not bode well for price regulation: the section was repealed because it proved unenforceable. ${ }^{58}$

Libraries as information generators. Finally, one should address the copyright role of libraries as originators of digital information. Digital libraries will compile online or disk-stored catalogs of their own and perhaps others' holdings. These catalogs may also include search programs to help users identify sources they seek from the mass of digital data. Having compiled the catalog or devised the search program, the library may be the holder of copyright in an "original work of authorship." The copyright laws would protect the library's exploitation of these works. However, if the catalog includes substantial portions of the listed works, the library may also be infringing third parties' copyrights.

Copyright in library catalogs. A catalog is a "compilation"; it is "formed by the collection and assembling of preexisting materials or of data that are selected, coordinated, or arranged." ${ }^{59}$ If the selection, coordination, or arrangement man- 
ifests a minimal degree of creativity, the catalog will be copyrightable. ${ }^{60}$ The U.S. Supreme Court recently denied copyright protection to a white-pages telephone directory. ${ }^{61}$ While the copyright threshold was very low, the Court believed that the phone book failed to meet it: its creation entailed no selection (the book listed all telephone subscribers in the locality), and no originality of arrangement (alphabetical). How would a library's digital catalog fare under the Court's analysis?

The selection criterion may not favor the library, at least not if the catalog covers the library's entire collection. While valuable for researchers, comprehensiveness may be counterproductive to asserting a copyright. Even so, if the catalog satisfies the arrangement criterion, that alone would support a copyright. The arrangement may be standard to the genre; for example, books might be retrieved according to author, title, or subject listings. Nonetheless, if the catalog includes some nonstandard features, it might manifest sufficient selection or arrangement of information to be considered minimally "original." These features might include atypical combinations of listings, ${ }^{62}$ or supplemental information, such as bibliographic references concerning some (but not all) other libraries' collections, or online services.

If the catalog is "original," copyright would protect it against unauthorized copying, but only to the extent that "original" material is copied. Thus, at least under current U.S. copyright law, downloading all the listings would infringe, but extracting standard information would not. ${ }^{63}$

Copyright infringement by libraries of works referenced in the catalogs and search programs. Imagine the following online catalog of a library's collection:

Level 1: Author, title, and subject listings

Level 2: Publisher-prepared abstract(s) of the chosen work(s)

Level 3: Excerpts from the chosen work(s), displayed in response to search terms selected by the researcher

Level 4: Full text of the chosen work(s)

This kind of catalog could be a very effective research tool, but portions of it also implicate rights in the referenced works. Level 1 does not raise a copyright issue, because this information is basic and involves minimal, if any, copying from the work. Level 2 is unlikely to offend the copyright laws, because the abstract contains the bare information necessary to identify the major ideas of the work. ${ }^{64}$ As such, either it is an uncopyrightable collection of "ideas," or copying it would be considered de minimis.

Level 3 becomes more troublesome, because the excerpts may be substantial. If so, they pose a prima facie case of infringement, which might be overcome by a fair use defense. Similarly, including full-text works might constitute either infringement or fair use. In both cases, the catalog and its search program, as imagined, would make it possible for the user to call up onscreen all or substantial 
parts of the digital work. If the catalog and search program do no more, these acts seem analogous to simply reading a hard-copy book and should not implicate copyright interests in the work viewed. However, if it is also possible for many users at one time to access the work in whole or in part, then the catalog is generating multiple copies of the referenced work, and this may exceed fair use bounds. By the same token, a "level 5 " that enabled users to download the works would provoke copyright conflicts, although one that permitted printouts of excerpts might not.

In many instances, the library's catalog will not be able to act independently of the laws covering the works it lists. The catalog might be viewed as a search tool that interacts with text files. But if the text files originate from a digital publisher, the library's agreement with the publisher will govern incorporation of the works in the catalog. Copyright in the listed works remains an issue for digital works generated by the library (for example, by scanning its hard-copy collection) and for which the library did not previously obtain permission to make these kinds of reproductions.

\section{Conclusion}

Legal analysis of copyright or contract rights in the library of tomorrow depends heavily on conditions that one can try to predict today, but that are likely to prove quite different tomorrow. Extrapolating from today's laws, and experiences in the transition to digital media, affords some guidance, but also highlights the shortcomings of analyses grounded in past presumptions derived from the capacities of print media. Existing copyright may be inadequate for the "library without walls." But substituting a contract regime may become far too burdensome, at least from the library's perspective. If the copyright doctrine of fair use survives the rise of contract in the digital world, it must be a different kind of fair use, one consciously adapted to the expanded capacities of digital communications. But its contours-never precise, even in the hard-copy worldcannot be articulated without a clearer picture of the kinds of contracts and communications the library of tomorrow will call into being.

\section{Notes}

Many thanks to Jim Hoover, Professor of Law and Law Librarian, Columbia University School of Law, and to Paul Smith, Columbia University School of Law, Class of 1993.

1. Although this essay primarily concerns U.S. copyright law, I will endeavor to point out parallels or contrasts with general principles of other Western copyright systems. 
In addition, although the law governing the relationship of copyright and libraries in the U.S. is rather detailed and technical, I will attempt to avoid entanglement in the minutiae of our domestic regime. This essay therefore should not be considered a primer on copyright and libraries in the U.S. For a fuller and more precise treatment of that topic, see, e.g., Randall Coyne, "Rights of Reproduction and the Provision of Library Services," Arkansas Little Rock Law Journal 13 (1991):485; Laurie C. Tepper, "Copyright Law and Library Photocopying: An Historical Survey," Law Library Journal 84 (1992):341

2. E.g., generally, Anne Okerson, "With Feathers: Effects of Copyright and Ownership on Scholarly Publishing," College and Research Libraries 52 (1991): 425-40; Nancy Marshall, "Copyright and the Scholarly Community: The Library's Responsibility to Guarantee User's Rights," Paper delivered at the Fifth U.S.-Japan Conference on Libraries and Information Sciences in Higher Education, October 1992. See also Steven Gilbert and Peter Lyman, "Intellectual Property in the Information Age," Change 21 (1989): 22-30: "If higher education cannot effectively deal with these issues, vendors and funders will be less receptive to doing business with . . . colleges and universities."

3. See 17 U.S.C. $§ 106$ (1988) (rights under copyright).

4. See 17 U.S.C. $\$ \S 109(a), 202$ (1988) (distinguishing ownership of incorporeal copyright from ownership of the physical object).

5. In some countries, however, the owner is compensated each time a book is lent from a library to a user. Such a system is commonly called the "public lending right" (PLR), and, as of 1988, was in place in twelve countries. Jennifer M. Schneck, "Closing the Book on the Public Lending Right," New York University Law Review 63 (1988): 878, $880-81$ and $n$. 29. All but Germany have enacted the PLR as a regime separate from the country's copyright system (ibid., 897). In the U.K., the purpose of such differentiation is based on the notion that PLR is merely a payment to the author for a "service" rendered; Brigid Brophy, A Guide to the Public Lending Right (Aldeshot, Eng., 1983), 53. Others have suggested a less objective purpose: that a country adopting the PLR and incorporating it into the copyright regime would have to recompense foreign authors under the Berne and Universal Copyright Conventions. See Schneck, "Closing the Book," 898.

6. For U.S. law see, e.g., Paul Goldstein, Copyright: Principles, Law, and Practice (Boston, 1987), § 10.2.2.1 (a noncommercial, nonprofit activity "would support a presumption that the use is fair"). For U.K. law see, e.g., E. P. Skone James et al., Copinger and Skone James on Copyright, 12th ed. (London, 1980), §513 (need for fair dealing arises only after a substantial portion of the work has been taken). For French law, see France, Code of Intellectual Property, art. 122-25, 20 (permitting copying for private use).

7. For a helpful general review, see generally Tepper, "Copyright Law and Library Photocopying."

8. See, e.g., Berne Convention for the Protection of Literary and Artistic Works, art. 9.2, September 1886, 828 U.N.T.S. 221 (hereinafter Berne Convention): "It shall be a matter for legislation in the countries of the Union to permit the reproduction of such works in certain special cases, provided that such reproduction does not conflict with a normal exploitation of the work and does not unreasonably prejudice the legitimate interests of the author."

9. See 17 U.S.C. $§ 107$ (1988), setting forth four factors that courts shall take into account: "(1) the purpose and character of the use, including whether such use is of a commercial nature, or is not nonprofit educational purposes; (2) the nature of the copyrighted work; (3) the amount and substantiality of the portion used in relation to 
the copyright work as a whole; and (4) the effect of the use upon the potential market for or value of the copyrighted work." The Supreme Court has stated that the fourth factor (economic harm) "is undoubtedly the single most important factor," Harper \& Row v. Nation Enters., 471 U.S. 539, 566 (1985). Compare Meeropol v. Nizer, 417 F.Supp. 1201, 1205-6 (S.D.N.Y. 1976), aff'd in part, rev'd in part 560 F.2nd 1061 (2nd Cir. 1977): "Courts in recent years have come to recognize that there are occasionally situations in which the copyright holder's interest in a maximum financial return must occasionally be subordinated to the greater public interest in the development of arts, science, and industry."

10. See 17 U.S.C. $\$ 108(1988)$.

11. By "archival copying," I mean copying to preserve a document from degradation or destruction, when a replacement is not available. See 17 U.S.C. $\S 108$ (c).

12. For example, $\S 108(\mathrm{~d})$ and (e) of the 1976 Copyright Act authorize copying for interlibrary loan, but only so long as the copy goes to the user; the requesting library may not retain the copy.

13. See 17 U.S.C. $\S 108(d)$ and (e). Section 108(f)(1) of the Act also exempts libraries from liability for copies made by patrons engaged in "unsupervised use of reproducing equipment located on [library] premises," without limitation as to the patrons' purposes for making the copies.

Under many foreign copyright laws, the kind of copying $\S 108(f)(1)$ addresses would most likely be considered "private copying," and therefore exempt. By contrast, copies made by third parties, even for the user's private enjoyment, might not qualify for the private copying exemption. See, e.g., Cass. civ. lre, Decision of 7 March 1984, 1985 (Juris-Classeur Periodique) II 20351, note R. Plaisant (Fr.) [“affaire RannouGraphie"] (for private copying exemption to apply, the user must make the copies). The World Intellectual Property Organization has proposed permitting certain kinds of library provision of reproductions to patrons, but only if no collective licensing arrangement is available for the territory concerned. The WIPO proposal would permit libraries to make free copies for purposes of replacement or conservation. See WIPO, Committee of Experts on a Possible Protocol to the Berne Convention for the Protection of Literary and Artistic Works, $§ 88(\mathrm{a})$ and (b), reprinted in Copyright 28 (1992): March, 70-71.

14. Particularly when they can pass along the copying costs to their own clients, see American Geophysical Union v. Texaco, Inc., 802 F. Supp. 1, 26 n. 24 (S.D.N.Y. 1992).

15. On the CCC and its work with university libraries, see, e.g., Jane C. Ginsburg, "Reproduction of Protected Works for University Research or Teaching," Journal of the Copyright Society 39 (1992): 181, 208-11, 216 and works cited therein. See also Tepper, "Copyright Law and Library Photocopying," 357-58, and Coyne, 485, n. 5, and 49950 (discussing role of CCC in photocopying liability cases). Compare William Patry, The Fair Use Privilege in Copyright Law (Washington, D.C., 1985), 320-32 (discussing library photocopying and fair use in light of legislative history of $\S 108$ ).

16. On collective licensing societies in other countries, see Stanley Besen and Sheila N. Kirby, Compensating Creators of Intellectual Property: Collectives That Collect (Santa Monica, Calif., 1989); Stanley Besen et al., "An Economic Analysis of Copyright Collectives," Virginia Law Review 78 (1992): 383, 388, n. 23, and 408, n. 95; Gunnar Karnell, "The Legal Situation Concerning Reprography in the Nordic Countries," International Review of Industrial Property and Copyright Law 15 (1984): 685; Jon Rudolph, "Licensing, Collecting, and Clearing for Reprographic Rights," Copyright 23 (1987): 148.

17. A printout is a traditional form of reproduction. Storage on a disk or in the computer's 
fixed memory is also a reproduction, even though the copy is not directly perceptible. Viewing the work onscreen requires storage of the work in the computer's volatile memory. Although the work will be erased from that memory once the machine is turned off, both U.S. and European Community copyright law have determined that the temporary storage nonetheless constitutes a reproduction. See, e.g., the 1978 Commission on New Technological Uses of Copyrighted Works (CONTU) final report, "The Input Issue," excerpted in Alan Latman, Robert A. Gorman, and Jane C. Ginsburg, Copyright for the Nineties, 3rd ed. (Charlottesville, Va., 1989), 166-68, concluding that inputting into a computer's random, erasable memory, constitutes a reproduction. CONTU's recommendations were codified in 1980 at 17 U.S.C. $\S \S 101$, 117 (1988). See also European Council Directive on the Legal Protection of Computer Programs, 91/250 1991 O.J. (L 122), art. 4(a) (hereinafter EC Directive). "Restricted acts" include inputting.

18. ASCII stands for "American Standard Code for Information Interpretation," and is the most unadorned machine readable text form, consisting only of characters without formatting information (such as "bold face" or "underline"). ASCII files can be transferred between machines operating on incompatible formats, such as IBM and Macintosh.

19. Arguably, the library should be entitled to make a free copy only of the image file, and not of the text file, because the latter is a second reproduction, and is not strictly necessary to preserving the document. On the other hand, the text file enhances access to the work, and the purpose of preserving the work would be not only to possess it, but to be able to make it available to readers. Conversion of the image file to a text file is probably consistent with the policies underlying library copying exemptions; the tensions with copyright are more likely to arise over the exploitation of the text file, rather than over its creation.

20. See note 17 above. In addition, sending the text from the library's files to the user's workstation is a "public performance" by means of transmission; see 17 U.S.C. $\$ 101$ (1988). Cf. On Command Video v. Columbia Pics., 777 F.Supp. 787, 789-90 (N.D. Cal. 1991) (hotel's transmission of video cassettes of motion pictures to guest rooms constituted public performance, even though no more than one guest room could access a particular film at any time).

21. See L. Ray Patterson, The Nature of Copyright: A User's Guide (Athens, Ga., 1991), 218, discussing library access in a fair use analysis. All copyright limitations, including fair use, are grounded in the purpose of advancing knowledge and promoting welfare; Patterson, 2. Patterson, "Understanding Fair Use," Law छ Contemporary Problems 29 (1992):265 ("Fair use ceases to be viewed as taking advantage of the copyright owner and becomes, instead, a recognized right of the user.").

22. Cf. House Conference Report no. 94-1733, 94th Cong., 2nd sess. 72-73, reprinted in U.S.C.C.A.N. 5810, 5813-14 (under CONTU guidelines, interlibrary loan requests within one calendar year of more than six copies from one periodical-entire serial, not merely a single issue-constitute a "substitution of subscription," and exceed the scope of free copying under $\S 108[\mathrm{~g}][2])$.

23. Herbert Howell, Howell's Copyright Law (Washington, D.C., 1942) (currently William Patry, Latman's The Copyright Law, 6th ed.; [Washington, D.C., 1986]).

24. However, if an "unused replacement" is not available at a "fair price," the library may make a replacement copy. See 17 U.S.C. § 108(c)(1988). On the other hand, § 108(a) limits the library's reproduction to "no more than one copy."

25. 17 U.S.C. $\$ 108(\mathrm{~g})(1)(1988)$. 
26. See 17 U.S.C. $\S 108(\mathrm{~g})(4)$ (1988). Whether libraries can "contract out of" their and their users' fair use privileges will be discussed below.

27. In fact, this is already happening in the dissemination of works on CD-ROM. Publishers are distributing these works to libraries subject to "site licenses" that exclude certain acts, such as interlibrary loan, or dissemination to users in sections of the university outside the library's normal users, as is permissible under the statutory library copying exemptions.

28. In U.S. law, this kind of copying would probably be considered a fair use under 17 U.S.C. $\$ 107$; in many other copyright laws, this copying would be considered "private," and therefore exempt, or would qualify for exemption because of its brevity.

29. See 17 U.S.C. § 108(e) (1988).

30. See Berne Convention, art. 9.2.

31. See 17 U.S.C. § 108 (f)(1) (1988).

32. The distinction drawn here between hard copy and digital copying assumes that the former does not pose a threat of multiple and multigenerational copying. This distinction may lose significance as optical scanning technology improves and comes within the reach of the average consumer. At that point, the user will be able quickly and easily to convert the hard-copy reproduction to digital format.

33. 17 U.S.C. $\& 108(g)(2)(1988)$.

34. For convenience, I am defining "tomorrow's" library to include digital media to which the library subscribes, even though some of today's libraries already obtain many documents in CD-ROM or online form.

35. White-Smith Music Pub. Co. v. Apollo Co., 209 U.S. 1, 19 (Holmes, J. concurring) (1908).

36. Although, I may ultimately find out, if the library is making the copy and has a license with a collective licensing authority that requires the library to track its copying.

37. Some libraries, such as the Library of Congress and the Bibliothèque de France, are national deposit libraries. Domestic copyright or other law requires deposit of copies of the work in the national library. See, e.g., 17 U.S.C. $\$ 407$ (1988) (Deposit to the Library of Congress); France, J.O. 1 July 1943, pp. 1778-79, D.C.L. Loi no. 341, 21 June 1943.

But deposit does not of itself entitle the library to copy the work. Having secured the copy by legal compulsion, the library may be able to avail itself of applicable library copying or fair use exemptions in copyright law to engage in limited disclosure of the work. Wider dissemination, however, will require permission.

Libraries that are not national deposit institutions may have difficulty making acquisitions from digital publishers. Similarly, digital publishers may be reluctant to authorize a national library to permit access to and copying of the work to any greater extent than the limited amount to which it is entitled under applicable copyright laws' free copying privileges-as adjusted to take account of digital media.

38. 17 U.S.C. \& $108(f)(4)(1988)$. As indicated earlier, libraries are in fact being asked to forgo some of their copying privileges in return for "site licenses" from publishers of digital media. One might inquire why publishers of hard-copy media did not seek to contract out of library copying privileges. The answer may be that, even if the thought of doing so had occurred, it is too difficult to control the copying of hard-copy media, especially when the document is available from sources other than directly from the publisher.

39. Ibid.

40. See H.R. Rep. no. 94-1476, 94th Cong., 2nd Sess. at 74, reprinted at 1976 U.S.C.C.A.N. 5659, 5687-88 (hereinafter "House Report" citing to U.S.C.C.A.N.): 
"The doctrine of fair use applies to library photocopying, and nothing contained in section $108 \ldots$ is intended to take away rights existing under the fair use doctrine. To the contrary, section 108 authorizes certain photocopying practices which may not qualify as fair use."

41. See 17 U.S.C. $§ 301$ (1988).

42. Copyright protects "original works of authorship," 17 U.S.C. $\S 102(a)$ (1988), but the standard of originality is very low. See, e.g, Feist Pubs. v. Rural Tel. Serv., 111 S.Ct. 1282, 1288 (1991); Atari v. Oman, 979 F.2nd 242, 244-45 (D.C. Cir. 1992).

43. 17 U.S.C. $\$ 106(1)$ (1988). Arguably, the right sought to be enforced by contract is not "equivalent" because it is not freighted with the limitations that attend rights under copyright (section 106 makes its grant of rights "subject to sections 107 [fair use] through 120"). However, Congress intended to preempt state laws granting greater protection as well as state laws granting identical protection. See House Report, above note 40, at 5746: "The preemption of rights under State law is complete with respect to any work coming within the scope of the bill, even though the scope of exclusive rights given the work under the bill is narrower than the scope of common law rights in the work would have been."

44. Smith $v$. Weinstein, 578 F.Supp. 1297, 1307 (S.D.N.Y.), aff'd without opinion, 738 F.2nd 419 (2nd Cir. 1984). Accord, Acorn Structures, Inc. v. Swantz, 846 F.2nd 923, 925 (4th Cir. 1988); Gorman, "Fact or Fancy?: The Implications for Copyright," Journal of the Copyright Society 29 (1982): 560, 605-10. See also House Report, above note 40, at 5747: "Nothing in this bill derogates from the rights of parties to contract with each other and sue for breaches of contract." This quotation taken from the House Report accompanying the bill that became the 1976 Copyright Act does not end the analysis, because the quote describes a portion of the bill that was subsequently deleted.

45. 17 U.S.C. $\S 102$ (b) (1988).

46. Cf. Bonito Boats, Inc. v. Thunder Craft Boats, Inc., 489 U.S. 118, 151 (1989) (holding a state law forbidding copying of unpatented boat hulls preempted by federal patent law; the Supreme Court declared that the patent laws "embody a congressional understanding, implicit in the Patent Clause itself, that free exploitation of ideas will be the rule, to which the protection of a federal patent is the exception. . . The federal patent laws must determine what is protected, but also what is free for all to use."

47. See Kewanee v. Bicron, 416 U.S. 470, 479 (1974).

48. See Restatement of Unfair Competition $\S \S 40-43$. Other trade secret cases involve acquisition of the information through other wrongful means, such as fraud or trespass. Rarely does a successful trade secret claim protect the information itself, when there is no conduct that is otherwise wrongful. But see ibid. $\S 43$, ill. 5 (flying over a factory and taking photographs to discover a trade secret, while not trespass, nonetheless violates the trade secret).

49. Cf. EC Directive, above note 17, at arts. 5.3, 6, and 9 (establishing mandatory software user rights to analyze and decompile the program).

50. See generally, Wendy Gordon, "Fair Use as Market Failure: A Structural Analysis of the Betamax Case and Its Predecessors," Columbia Law Review 82 (1982): 1600; Goldstein, above note 6 , at $\S \S 10.1 .1-10.1 .3$. See also American Geophysical Union, 802 F.Supp. 1, 24-26 (S.D.N.Y. 1992) (rejecting fair use claim by for-profit corporation whose researchers photocopied from scientific journals). The American Geophysical court distinguished Williams छ Wilkins Co. v. U.S., 487 F.2nd 1345 (Ct. Cl. 1973), aff'd by an equally divided court, 420 U.S. 376 (1975)—which had found photocopying by the National Institutes of Health to be fair use-on the ground that at that time, no 
"convenient, reasonable licensing system" was available, while such licenses were available (from the CCC) today (at 25).

51. American Geophysical Union, 802 F.Supp. at 250.

52. See, e.g., Rosemont Enters. v. Random House, 366 F.2nd 303, 307 (2nd Cir. 1966): “The [fair use] practice is permitted . . . so that the world may not be deprived of improvements, or the progress of the arts retarded") (quoting Sayre v. Moore, 102 Eng. Rep. 138, 139 [K.B. 1801]). See also L. Ray Patterson, User's Guide, 102, noting that fair use is central to balancing author's rights in furthering goal of learning: "Access to copyrighted materials is necessary if that fundamental goal is to be fulfilled."

53. See generally Pierre Leval, "Toward a Fair Use Standard," Harvard Law Review 103 (1990): 1105, 1111-16 (stressing the claims of "transformative uses" to the fair use exemption).

54. See Leon Seltzer, Exemptions and Fair Use in Copyright (Cambridge, Mass., 1978), 24 (rejecting application of fair use privilege to "intrinsic uses").

55. Cf. Sony Corp. of America v. Universal City Studios, 464 U.S. 417, 455 n. 40 (1984) (stating that copying for "personal enrichment" can qualify as a fair use).

56. An alternative is to permit the publishers to set their own rates, subject to judicial review for reasonableness. See In Re Turner, 1991 WL 331491 (Aug. 8, 1991 S.D.N.Y.) at *1 (challenge, pursuant to terms of antitrust decree governing ASCAP's activities, to ASCAP's rates for blanket license to cable operators).

57. 8 Anne c. 19, sec. IV. On this provision, see generally, Harry Ransom, The First Copyright Statute (Austin, Tx., 1956), 96, 101-2.

58. See Act of 12 George II (1739); Ransom, First Copyright Statute, $107 \mathrm{n}$. 13. See also John Feather, A Dictionary of Book History (New York, 1986), 79-80 (discussing history of Act).

59. 17 U.S.C. $§ 101$ (1988).

60. See Feist Pubs. v. Rural Tel. Serv., 111 S.Ct. 1288, 1294 (1991).

61. Ibid. at 1295-97.

62. See, e.g., Key Pubs., Inc. v. Chinatown Today Pub. Enters., 945 F. 2nd 509, 512, 515-16 (2nd Cir. 1991) (unusual listings in plaintiff's Yellow Pages of Chinese businesses met originality standard).

63. The EC Commission has proposed a Directive on the Legal Protection of Databases that would afford not only copyright protection to original electronic compilations, but a new "right to prevent unfair extraction" of nonoriginal material; COM (92) 24 Final at arts. 2.5, 8.

64. Or because the publisher-supplied abstract comes with permission to make this kind of use. 